\title{
AZ ALFÖLD KUTATÁSI PROGRAM ÉS A KUTATÁS DOKUMENTUMAI
}

Az Alföldrôll szóló országgyũlési és kormányhatározatban foglaltak alapján a Környezetvédelmi és Területfejlesztési Minisztérium kutatási szerzódésben bízta meg az MTA Regionális Kutatások Központja Alföldi Tudományos Intézetét, hogy a korábbi és a jelenleg folyó kutatások eredményeire alapozva dolgozza ki az Alföld hosszú és rövid távú területfejlesztési, tájfejlesztési (tájvédelmi és tájhasznosítási) koncepcióját. Az Intézet e feladat koordinálására, az úgynevezett akciókutatás lebonyolítására programirodát szervezett Kecskeméten, majd a régió különbözố egyetemein, kutatóhelyein, regionális közintézményeiben, megyei önkormányzataiban dolgozó kutatók és szakemberek bevonásával 21 tagú tudományos tanácsot hívott létre. A tanács meghatározta a kutatás legfontosabb általános alapelveit, a tematikus vizsgálatok fó irányait, folyamatosan figyelemmel kísérte a kutatási program menetét, véleményezte az elkészült köteteket, majd megvitatta és véglegesítette a koncepciót.

$\mathrm{Az}$ Alföldrốl szóló korábbi és folyamatban lévố kutatások eredményeit kilenc, tematikusan összefüggõ, közel kétezer kézirati oldalt tartalmaź kötetben összegeztük. Ezek elkészítésében 96 különbözõ tudományterületet mũvelô kutató és szakember vett részt elótanulmányok írásával, szakmai véleményekkel, dokumentumokkal. A kötetek több oldalú megközelítésben - makroregionális elemzéseket adtak az Alföldrõl. Elkészült a rövid és hosszú távú koncepció tervezete $(X-X I$. kötet) és az alulról építkezó regionális fejlesztés lehetséges kistérségeit taglaló XII. kötet. A kutatómunka széles körũ véleményezés után a XIII. kötettel zárult.

A kutatás folyamán az Országos Mûszaki Fejlesztési Bizottság pályázati támogatásával a programiroda alföldi adatbázist alakított ki többféle hivatalos és egyedi adatgyưjtés, felmérés elvégzésével. Ennek és a MAPINFO programcsomagnak a segítségével a kutatókat támogató térinformatikai rendszer jött létre, melynek eredményeként számos táblázat és térkép tette szemléletesebbé a tanulmányokat és a köteteket.

A kutatási elốtanulmányokat és a köteteket, valamint az alföldi adatbázist az Alföldi Tudományos Intézet dokumentálta, ezek a kutatók és érdeklōdôk rendelkezésére állnak. Jelen bibliográfiánkkal a további kutatásokhoz kívánunk segítséget nyújtani.

I. Alföld Kutatási Program. Készült a Környezetvédelmi és Területfejlesztési Minisztérium megbízása alapján a MTA Regionális Kutatások Központja Alföldi Tudományos Intézetében. (Kiad.) MTA RKK Alföld Projekt Programiroda. Kecskemét, 1992-1993. Kéziratként sokszorosítva. 
Az Alföld fejlesztés (elổzetes) tézisei. Írták: Csatári Bálint, Illés Iván. 210.

I. kötet: Az Alföld népessége. Témavezetõ: Velkey Gábor. 2050.

II. kötet: Az Alföld környezeti állapota és természetvédelme. Témavezetô: Rácz Lajos. 219 o.

III. kötet: Az Alföld gazdasági bázisa. Témavezetõ: Hegedũs Miklós. 1500.

IV. kötet: Az Alföld agrártermelésének és élelmiszeriparának helyzete. Témavezetõ: Gurzó Imre. 239 o.

V. kötet: Az Alföld területhasznosítása. Témavezetô: Baukó Tamás. 168 o.

VI. kötet: Az Alföld településrendszere. Témavezetô: Tóth József. 197 o.

VII. kötet: Az Alföld infrastruktúrája. Témavezetô: Erdôsi Ferenc. 1950.

VIII. kötet: Az Alföld turizmusa. Témavezetô: Csordás László. 243 o.

IX. kötet: Az Alföld önkormányzati struktúrája és a területfejlesztés összefüggései. Témavezetô: Pálné Kovács Ilona. 1050.

$X$. kötet: Az Alföld hosszú távú területfejlesztési és tájhasznositási koncepciója (tervezet). Témavezetô: Illés Iván. 1420.

XI. kötet: Az Alföld rövid távú területfejlesztési koncepciója (tervezet). Témavezetó és szerzố: Illés Iván. 97 o.

XII. kötet: Az Alföld kistérségei. Témavezetô és szerzõ: Beluszky Pál, Csatári Bálint. 67 o.

XIII. kötet: Az Alföld fejlesztési koncepciója. Témavezetố: Illés Iván. 194 o.

XIV. kötet: Az Alföld fejlesztési koncepciója. Tartalmi összefoglaló. Írták: Csatári Bálint, Illés Iván. 24 o.

II. Alföld Kutatási Program elôtanulmányai. Készültek a Környezetvédelmi és Területfejlesztési Minisztérium megbízása alapján az MTA RKK Alföldi Tudományos Intézetében. (Kiad.) MTA RKK Alföld Projekt Programiroda. Kecskemét, 1992-1993. Kéziratok, melyek a kötetekben szerkesztett formában jelennek meg, archiválásukról az Alföldi Tudományos Intézet gondoskodott. (Zárójelben annak a kötetnek a száma, amelyben a tanulmány megjelent, vagy amelynek megírásához felhasználták.)

Abonyiné Palotás J: Az Alföld falusi településeinek infrastrukturális állapota. 18 o., 1 térkép. (X.)

Andó M.: Az Alföld természeti földrajzi kistáji környezeteinek potenciális értékei, különös tekintettel fejlổési lehetôségeire. 20 o. (X.)

Barta Gy. - Poszmik E.: Szerkezeti változások hatása az Alföld ipari fejlôdésére. 59 o. (III.)

Baukó T.: A területhasználat néhány speciális konfliktusos esete. 16 o., 8 ábra. (V.)

Baukó T.: Az idegenforgalmi szálláshelyek, a beutazó turizmus és a fürdốk elemzése. 7 o., 8 ábra, táblázatok. (VIII.)

Becsei J. - Dövényi Z.: A foglalkozási szerkezet és a munkanélküliség strukturális jellemzôi és területi különbségei az Alföldön. 14 o., 2 ábra. (I.)

Becsei J.: A külterületi települések átalakulása. 10 o., 3 ábra, 3 táblázat. (X.)

Becsei J.: Az alföldi városok átalakulása. 10 o. (X.)

Berényi I.: A területhasznosítás új problémái az Alföldön. 9 o. (V.) 
Bokody J.: A víziturizmus jellemző̉, fejlesztési lehetôségei az Alföldön. 38 o., mellékletek: táblázat, térkép, vázlatrajz, prospektus (VIII.)

Bổhm A. - Szổgyi L. - Táll É.: Társadalmi kapcsolatok és kötôdési módok SzabolcsSzatmár-Bereg megye három településén. 28 o. (I.)

Csapóné Tábori H.: A nemzeti parkok és az idegenforgalom. 13 o. (VIII.)

Csató É.: Térszerkezeti változások a tanyás térségekben a nagyüzemi gazdálkodás kezdete óta. 15 o., 1 ábra. (V.)

Csordás L.: A falusi turizmus helyzete, problémái az Alföldön. 13 o., 2 táblázat, 3 ábra. (VIII.)

Csordás L.: Az alföldi idegenforgalom fejlesztése, üdülôkörzetek, projektek. 32 o. (VIII.)

Csordás L.: Hobby-turizmus. 2 o. (VIII.)

Csordás L.: Magánüdülök az Alföldön. 14 o., 8 ábra. (VIII.)

Dömsödi J:: Az Alföld tôzeges láptalajú területeinek bemutatása, megóvásuk lehetôségei. 23 o., 1 ábra. (II.)

Eke P.-né: Szabolcs-Szatmár-Bereg megye falusi térségeinek speciális demográfiai jellemzối. 15 o., 3 ábra. (I.)

Emõdi É.: Az épített (mũvi) környezet értékelése, a nemzetiségek és a folklór szerepe a rekreációban. 17 o. (VIII.)

Erdôsi F.: A közlekedési-hírközlési-távvezetékes (vonalas) infrastrukturális ellátottság területi jellemzối az Alföldön. 63 o., 36 ábra. mellékletek. (VII.)

Forray R. K.: Az Alföld oktatásügye. 28 o. (I.)

Futó P.: A gazdasági rendszerváltás Orosháza iparában. 21 o. (III.)

Gábris Gy.: Az Alföld vízrajzának jellegzetességei. 48 o. (II.)

Gurzó I.: Az alföldi élelmiszergazdaság fejlesztésének néhány kérdése. 16 o. (IV.)

Hanyecz V.: A mezôgazdasági infrastruktúra területi jellegzetességei az Alföldön. 24 o. 16 melléklet. (IV.)

Horváth Benổ: Az Alföld környezeti és ökológiai stratégiájának fổbb elemei. 3 o. (XIII.)

Horváth J. - Lánszki I.: Az Alföld, mint élelmiszertermelô régió nemzetgazdasági jelentôsége. 12 o., 23 o. (IV.)

Illés I.: Az infrastruktúra helye a korszerũ terület- és településfejlesztésben. 17 o. (VII.) Iván L.: Középfalvak helyzete - egy településtípus státusváltozása - az Alföldön. 8 o., 9 táblázat, 8 ábra. (X.)

Iván L.: Külföldi tốkeérdekeltségú vegyesvállalatok az Alföldön. 10 o. 6 táblázat, 4 térkép. (XIII.)

Keveiné Bárány I.: Az Alföld agroökoszisztémán kívüli területeinek flórája és faunája. 7 o. (II.)

Kocsis K.: Az Alföld etnikai struktúrája. . (I.)

Kollarik A.: A turizmus szerepe, nemzetgazdasági jelentôsége az Alföldön. 17 o., 1 térkép. (VIII.)

Kovács Cs.: Az alföldi népesség jövedelmi helyzete és jövedelmi viszonyai 1962-1990 idõszakában. 4. (I.) 
Kovács T.: Az alföldi agrárnépesség szociológiai vizsgálata. 53 o.(IV.)

Kovács Z.: Az alföldi társadalom politikai strukturálódása az 1990. évi parlamenti választások tükrében. 10 o. 5 térkép. (I.)

Kốszegfalvi Gy.: Az Alföld infrastrukturális ellátottságának különleges jellemzôi és a fejlesztéshez a térségi sajátosságok figyelembevételével adható speciális szempontok. 39 o. (VII.)

Krassó S.: Az Alföld lakossági-települési infrastruktúrájának fổbb fejlettségi tényezôi. (VII.)

Kugler J.: Az Alföld területhasznosításának elmúlt századai. 8 o., 9 táblázat. (V.)

Kürti Gy.: A terület- és földhasznosítás változása Csemỏben. 3 o., 6 térkép. (V.)

Lánszki I.: Az Alföld földhasználata és a tájökológia összefüggései. 29 o. (V.)

László M.: Az önkormányzatok gazdálkodási jellemzổi az Alföldön különbözố önkormányzati típusok alapján. 5 o., 16 táblázat (IX.)

Lengyel I.: A lakossági megtakarítások és adósságok területi sajátosságai az Alföldön. 23 o., 6 térkép. (I.)

Lovas I.: A Nyírség komplex agrárfejlesztési programja és metodikája. 26 o. (IV.)

Lovas I.: Az alföldi egyéni vállalkozó és gazdálkodó paraszti rétegek helyzetének vizsgálata az átalakuló mezốgazdaságban. 41 o. (X.)

Mayer A. - Szappanos G. - Ekerl A.-né: Az alföldi termáltelepülések helyzete. 33 o., 1 táblázat, 1 térkép. (VIII.)

Márton J.: Az Alföld élelmiszergazdaságában szükséges szerkezetváltás idôszerũ kérdései. 28 o. (IV.)

Meggyesi T.: Az Alföld építészeti értékeinek hagyományai és megôrzố továbbfejlesztésének lehetôségei. 20 o., 7 ábra. (XIII.)

Mezốsi G.: Az Alföld geomorfológiai és talajtani állapota. 4. o. 17 térkép. (II.)

Mika J. - Nemes Cs.: Az Alföld éghajlati állapota és a globális klímaváltozás valószínũ helyi sajátosságai. 88 o. (II.)

Nagy I.: Az alföldi településformák környezetmodelljei. 21 o. (II.)

Nemes Nagy J.: A gazdaság regionális állapota és folyamatai. 35 o., 4 táblázat, 2 térkép. (XIII.)

Nemes Nagy J.: Az Alföld a hazai regionális gazđasági fejlôdésben és regionális politikában. 29 o. (XIII.)

Ónodi G.: A falufejlesztés és falutervezés speciális igényei I. 20 o. (X.)

Orosz É.: Az Alföld egészségügyének néhány kérdése. 17 o. (I.)

Pálné Kovács I.: Az Alföld fejlesztési programjának irányítási összefüggései. 32 o. (XIII.)

Pálné Kovács I. : Közigazgatás és területfejlesztés az Alfölđön. 31 o. (IX.)

Puskás Cs.: A Tisza-tó és térségének fejlesztési lehetôségei. 22 o. (X.)

Puskás Cs.: Az üdülés, pihenés, rekreáció helyzete és fejlesztési lehetốségei a Tisza-tó térségében. 17 o. (VIII.)

Rácz E.: Elemzés az Alföld élelmiszeriparáról. 28 o. (IV.)

Rechnitzer J.: Az innovációk által szabdalt Alföld. 45 o. (XIII.) 
Reischl G.: A falufejlesztés és falutervezés speciális igényei, lehetôségei és korlátai az Alföldön II. 14 o. (X.)

Rétvári L.: Az Alföld természeti erőforrásai. 35 o. (X.)

Somogyi S.: Az Alföld kistájainak ökológiai állapota. 26 o., 18 melléklet. (II.)

Somogyi S.: Az Alföld üdülési, turisztikai és rekreációs adottságai. 26 o., 19 táblázat. (VIII.)

Somogyi S.: Az alföldi vízrendezések társadalmi-gazdasági-ökológiai következményei. 45 o. (II.)

Somogyi S.: A természeti környezet történelmi birtokbavételének folyamata az Alföldön 1945-ig. 53 o. (II.)

Soós Z.: Idegenforgalom a Kiskunsági Nemzeti Parkban. 11 o. (VIII.)

Süli-Zakar I.: Bodrogköz: az átalakított kistáj. 24 o., mellékletek. (V.)

Szabó G.: A falusi-tanyai turizmus fejlesztésének és szervezésének feltételei az Alföldön. 23 o. (VIII.)

Szoboszlai Zs.: Az önkormányzatok integrációs gyakorlata az Alföldön. 62 o. (IX.)

Timár J.: Az alföldi városok szuburbanizációja. 15 o., 4 táblázat. (Vl.)

Tóth J.: Az Alföld népesedési folyamatai, a népesség területi elhelyezkedése és demográfiai jellemzổi. 50 o. (I.)

Tóthné Hegyvári G.: A második otthonok. 30 o. (VIII.)

Valér É.: Az Alföld településállománya, változásai és fejlôdési tendenciái. 42 o., 21 táblázat, 3 térkép. (VI.)

Valér É.: Az Alföld ipara, munkaeröhelyzete és infrastrukturális ellátottsága. 4 o. (III.)

Vámosi J.: Az Alföld területhasznosítási, felszínfedettségi és fizikai szerkezeti vizsgálata. 42 o. (V.)

Winkler Gy.: A területfejlesztést leginkább szolgáló állami szerepvállalás összetevôii. 23 o. (III.)

Zentay T.: Az Alföld agrogeológiai potenciálja mint a fejlódés egyik mozgatórugója. 43 o. (X.)

Zoltán Z.: Az új típusú kistérségi területfejlesztési beavatkozások lehetôségei és korlátai az Alföldön. 32 o. (X.) 